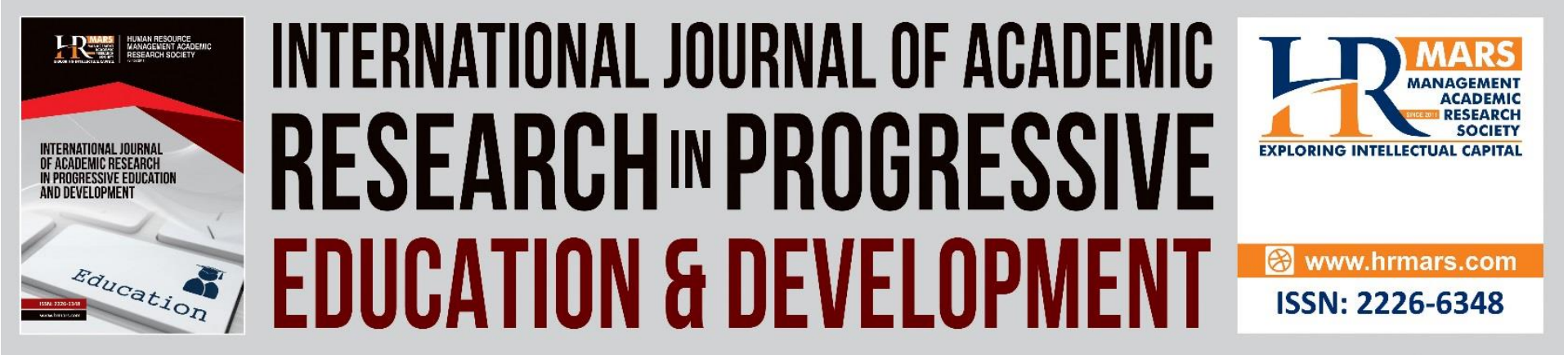

\title{
Youth Engagement in the Implementation of The Sustainable Development Goals (SDGS) in Asean Countries
}

Mohd Idham Mohd Yusof and Mariani Ariffin

To Link this Article: http://dx.doi.org/10.6007/IJARPED/v10-i3/10359

DOI:10.6007/IJARPED/v10-i3/10359

Received: 11 July 2021, Revised: 14 August 2021, Accepted: 30 August 2021

Published Online: 17 September 2021

In-Text Citation: (Yusof \& Ariffin, 2021)

To Cite this Article: Yusof, M. I. M., \& Ariffin, M. (2021). Youth Engagement in the Implementation of The Sustainable Development Goals (SDGS) in Asean Countries. International Journal of Academic Research in Business and Social Sciences, 10(3), 956-974.

Copyright: (C) 2021 The Author(s)

Published by Human Resource Management Academic Research Society (www.hrmars.com)

This article is published under the Creative Commons Attribution (CC BY 4.0) license. Anyone may reproduce, distribute, translate and create derivative works of this article (for both commercial and non-commercial purposes), subject to full attribution to the original publication and authors. The full terms of this license may be seen

at: http://creativecommons.org/licences/by/4.0/legalcode

Vol. 10(3) 2021, Pg. 956 - 974

Full Terms \& Conditions of access and use can be found at http://hrmars.com/index.php/pages/detail/publication-ethics 


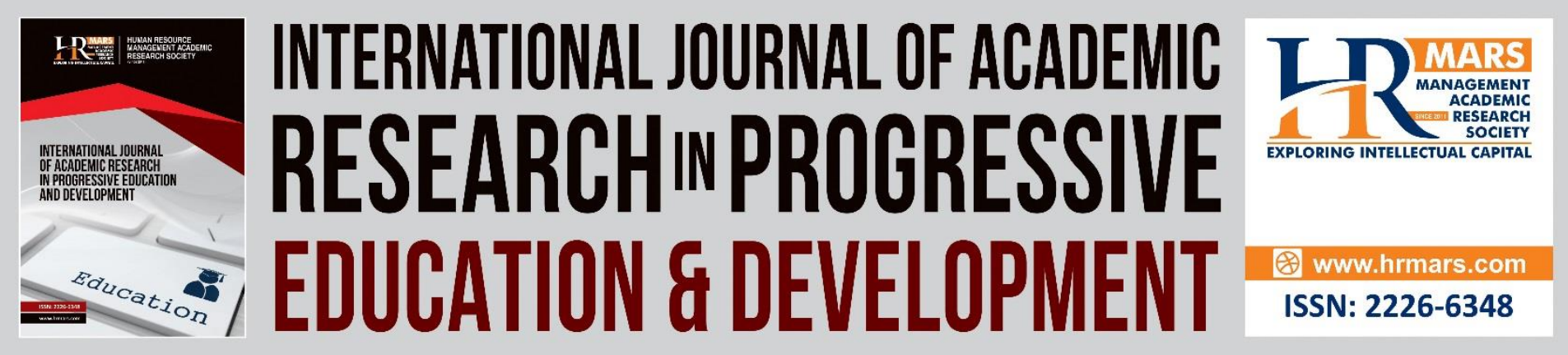

\title{
Youth Engagement in the Implementation of The Sustainable Development Goals (SDGS) in Asean Countries
}

\author{
Mohd Idham Mohd Yusof ${ }^{1,2}$ and Mariani Ariffin ${ }^{1}$ \\ ${ }^{1}$ Faculty of Forestry and Environment, Universiti Putra Malaysia, 43400 UPM Serdang, \\ Selangor, Malaysia, ${ }^{2}$ Faculty of Administrative Science and Policy Studies, Universiti \\ Teknologi MARA (UiTM), Seremban Campus, Persiaran Seremban Tiga/1, Seremban 3, \\ 70300, Negeri Sembilan, Malaysia.
}

\begin{abstract}
The implementation of the Sustainable Development Goals (SDGs) requires commitment from the United Nations (UN) members to meet the 17 goals. Therefore, the goals should be implemented at the national level, sub-national level, and also at the local level through a variety of national planning and policies. However, the SDGs progression needs to be monitored by the High-Level Political Forum (HLPF) and various UN Agencies to remain relevant as a global agenda. This paper attempts to analyse the initiatives of youth-centric SDGs among the Association of Southeast Asian Nations (ASEAN) countries. The primary reference in analysing the SDGs implementation and youth engagement process is the Voluntary National Review (VNR), National Development Plans (NDP), and the UN official reports. Evidence has shown that ASEAN countries have engaged with the youth in implementing SDGs, and have focused on youth, indicating the importance of the younger generation as one of the Major Groups and Stakeholders (MGoS) in accomplishing the national SDGs initiative. Nonetheless, more relevant and meaningful SDGs engagement is needed as the youth represents the present and future generation that is affected by sustainability issues. Hence, ASEAN countries should empower their younger generation by implementing more youth-SDGs-related programmes to fulfil each SDGs.
\end{abstract}

Keywords: Sustainable Development Goals (SDGs), Youth, Engagement, Voluntary National Review (VNR), Association of Southeast Asian Nations (ASEAN).

\section{Introduction}

The term "youth" and "young people" are used interchangeably in the SDGs to represent the voices of millennials towards sustainability. As one of the Major Groups and Other Stakeholders (MGoS) for the global agenda, the representation of the younger generation and their meaningful engagement are essential as the global young population is expected to reach 1.29 billion in 2030 (UNDESA, 2020b). At the ASEAN level, Southeast Asian countries are committed to linking the youth with 17 broad and ambitious goals of SDGs, which are SDG 
Vol. 10, No. 3, 2021, E-ISSN: 2226-6348 @ 2021 HRMARS

1 (No Poverty), SDG 2 (Zero Hunger), SDG 3 (Good Health and Well-Being), SDG 4 (Quality Education), SDG 5 (Gender Equality), SDG 6 (Clean Water and Sanitation), SDG 7 (Affordable and Clean Energy), SDG 8 (Decent Work and Economic Growth), SDG 9 (Industry, Innovation, and Infrastructure), SDG 10 (Reduced Inequalities), SDG 11 (Sustainable Cities and Communities), SDG 12 (Responsible Consumption and Production), SDG 13 (Climate Action), SDG 14 (Life Below Water), SDG 15 (Life on Land), SDG 16 (Peace, Justice and Strong Institutions), and SDG 17 (Partnerships for the Goals) (UNDESA, 2020a).

The ASEAN Youth Development Index (YDI) had also highlighted the youth participation and engagement, education, employment and opportunity, as well as health and well-being as the domains of the development. The integration of these SDG-relevant domains into government policies will create an inclusive, sustainable, resilient, and dynamic youth under the ASEAN Socio-Cultural Community (ASCC) 2025 Vision (The ASEAN Secretariat, 2017). Hence, 213 million youth in Southeast Asia should benefit from various SDGs initiatives and act as one of the key determinants in dealing with economic, social, and political challenges. This paper attempts to analyse the initiatives of youth-centric SDGs among the ASEAN countries in which the youth act as the recipient, initiator, and also as an partner of the sustainability agenda. The authors have also designed the Youth-SDGs Focus Mapping and Young Engagement Diagram to illustrate the results of the review.

\section{Methodology}

This paper reviewed the SDGs progress and initiatives undertaken by the countries in Southeast Asia. It was written based on a few primary sources: Voluntary National Reports (VNR) on SDGs, the countries National Development Plans (NDP), UN Reports, and the official data published from the year 2015 to 2021. Keywords such as "Youth", "Young People", "Young Generation", "Young Population", and "Teenagers" were used as a search string to identify policies, programmes, and initiatives relating to youth and the SDGs contained in the VNR and the NDP. The information was then mapped with the 17 SDGs to identify the countries Youth-SDG areas of concern and the youth engagement pattern.

\section{Current SDG's Progress in ASEAN Countries}

This section discusses the progress of SDGs among ASEAN countries by emphasising on youth-related policies, programmes, initiatives, and engagement approaches. All ASEAN countries have produced their VNR and presented it to the HLPF at the United Nations except for Brunei and Myanmar. Since the introduction of SDGs in 2015, only Indonesia has presented its VNR three times as evidence of its commitment to the country level's SDGs implementation. Indonesia frequent reporting in 2017, 2019 and 2021 could inspire other countries in the region to undertake more frequent reviews of their SDG implementation and contribute to national and global reporting.

\section{Brunei Darussalam}

Brunei Darussalam has not yet presented any VNR to the HLPF. However, its SDGs concept can be seen in the country development plans, such as the Brunei $10^{\text {th }}$ NDP (2012-2017), the $11^{\text {th }}$ NDP (2018-2023), and the Brunei Vision 2035. Indirectly, these country vision and development plans are relevant to the SDGs and will contribute to the countries' progression to achieve the Agenda 2030. With a focus on youth, Brunei Vision 2035 emphasises the importance of the younger generation in achieving the government's development vision. 
Vol. 10, No. 3, 2021, E-ISSN: 2226-6348 @ 2021 HRMARS

The country's youth have enormous responsibilities to comprehend the government's development agenda and to share the wisdom of the country's vision with their fellow youth. Within the context of the SDGs, Brunei's government will collaborate with a few UN agencies, including the United Nations Educational, Scientific, and Cultural Organisation (UNESCO), to reinforce their youth positions in accordance with SDG 16 on youth inclusion (UNESCO, 2018). Youth in Brunei will be regarded as significant stakeholders in the country policies process. At various levels, youth leaders and associations will be approached to promote sustainable livelihoods, promote peace, and prevent extremism. As active young citizens, their roles will conform with the UNESCO Operational Strategy on Youth (2014-2021) and United Nations Security Council Resolution 2250 on Youth, Peace, and Security (2015).

Apart from that, Brunei has been focusing on SDGs 4, 8, and 17 and connecting them to youth development through education and skill development programmes. The Brunei younger generation is the nation's main workforce, and their importance as the country's social capital has been stated in the Brunei NDP (2012-2017). Thus, the country aims for a consistent high economic growth that could offer more employment to the younger population (Department of Economic Planning and Development, 2012). Continuously, the youth has remained as the centre of attention to the Brunei NDP (2018-2023) through three major thrusts. The first and the second thrust of the plan aim to improve the education and provide high-skilled human capital (SDG 4 and 8). The third thrust of the NDP emphasises on creating and empowering a visionary community (including youth) that possesses "Wasatiah" (Moderation) in achieving its sustainable development agenda. In addition, Brunei also introduced "Skilling Brunei Darussalam", which aims to increase the youth competencies and encourage them to focus on entrepreneurship as a preparation to shift towards the non-oil and gas sector. The education system of Brunei, particularly that of technical and vocational, had undergone a significant transformation which emphasises Science, Technology, and Innovation (STI) (UNESCO, 2018). Besides, the enablers that comprise high-quality teachers, interactive pedagogy, and efficient school administrators were strengthened. Policy arrangements such as the $21^{\text {st }}$ Century National Education System (SPN21), Industry Competency Framework (ICF), Graduate Apprenticeship Scheme (i-Ready), National Entrepreneurship Agenda (NEA), and Brunei Entrepreneurship Education Scheme (BEES) 2.0 were introduced. Additionally, Brunei also established the Centre for Capacity Building (PPK), Youth Development Centre (PPB), Manpower Planning Unit, and JobCentre Brunei (JCB) through public-private initiatives (Department of Economic Planning and Statistics, 2020) in efforts to support transformation programmes and develop a skilled workforce capable of sustaining the country's development.

The Brunei NDP also emphasises on the nexus of youth, education, and Islamic values. Under the Compulsory Religious Education Order 2012, the government will build more Religious and Arabic Schools, in which the Ministry of Religious Affairs is responsible for inculcating Islamic principles and positive attitudes amongst the youth as a part of the country's vision to be a "Negara Zikir" (Department of Economic Planning and Statistics, 2020). In Brunei, the concept of development is inextricably linked to Islamic principles. As a result, it comes as no surprise that the country's concept of sustainable development is infused with religious elements as its primary guide. 
Vol. 10, No. 3, 2021, E-ISSN: 2226-6348 @ 2021 HRMARS

\section{Cambodia}

The VNR preparation of Cambodia that was based on the Cambodia Sustainable Development Goals (CSDG) framework, Cambodia Vision 2050, Rectangular Strategy Phase IV (RS-IV), and the National Strategic Development Plan (NSDP) 2019-2023, was led by the Ministry of Planning. The reports had declared that the CSDG progression is at "ahead" or "on track" level, particularly in its six key SDGs, which are SDG 4, 8, 10,13,16, and 17. The youth, who accounts for approximately two-thirds of the population of Cambodia, is one of the major SDGs stakeholders. Volunteering is the mechanism used for engaging the young people of Cambodia in CSDG 3, 4, 6, 11, 12, 16, and 17, and connecting institutional projects with disadvantaged and remote communities. Among those were the government and UN Volunteers (UNV) pilot voluntary projects and social entrepreneurship. The three pilot projects had tapped the full potential of young people by mobilising 1359 young volunteers in seven provinces, serving over 9000 people in organic farming, health, waste management, clean water, and sanitation since 2018. Another successful example was the Techo Voluntary Youth Doctors Association (TYDA), which had attracted 3600 young doctors to provide healthcare programmes that have benefited 240000 Cambodians (Ministry of Planning, 2019).

SDG 3 is one of the top priorities of the Cambodian government as health issues in the country require multi-sectoral and inter-sectoral reform. Lack of knowledge among the young people on the subject of sexual and reproductive health, and the increase in teenage pregnancies are the main concerns of the government apart from the high prevalence of HIV (Ministry of Planning, 2019). In the aspect of education in Cambodia, the youth is hoped to be able to achieve literacy and numeracy by 2030 (SDG 4). The strategies for educational improvement include adopting Science, Technology, Engineering and Mathematics (STEM) into the education system, creating financial sustainability, and implementing the National Strategy for the Development of Education Statistics (Ministry of Planning, 2019). As a result, there has been a rise in the school completion rate, improve the education enrolment rate and literacy rate. The youth in the country has been equipped with a technical and $21^{\text {st }}$ century set of competencies to prepare the youth as skilled labour (SDG 8) and also to encourage gender equality (SDG 5). Besides that, a five-year Action Plan to Prevent and Respond to Violence against Children (2017-2021) was created by the government to respond to violence against young population providing remedial and protection mechanisms to the victims and survivors as coordinated by the Ministry of Social Affairs, Veterans, and Youth Rehabilitation (MOSVY) (Ministry of Planning, 2019).

\section{Indonesia}

Indonesia had submitted its VNR in 2017, 2019 and 2021, which showed the tremendous efforts of the country in reporting its SDG progress. One of the most significant strengths towards Indonesia SDGs progression is that the commitment of the President and his government to implementing SDGs at the national, provincial, and grassroots levels. Apart from political will, Indonesia's strength in advancing the SDGs rests in the policy and institutional framework that placed the SDGs as the focal point. The SDGs in the country have been aligned with the Indonesian National Development Vision (Nawacita) and integrated with the 2015-2019 National Medium-Term Development Plan (RPJMN), which were then translated into the Government Work Plan (RKP). At the sub-national level, there is a MediumTerm Regional Development Plan (RPJMD) and a Regional Work Plan (RKPD) with the 
Vol. 10, No. 3, 2021, E-ISSN: 2226-6348 @ 2021 HRMARS

participation of multi-stakeholders (Ministry of National Development Planning, 2019). Additionally, the SDGs practice also has involved youth extensively and the engagement process was reported in the country VNR.

Despite the COVID-19 constraint, youth representatives in Indonesia are continuously engaged with the other stakeholders in the VNR preparation. Throughout the VNR 2021, the input of youth and other stakeholders were gathered through an online mechanism and various consultation series. This ensures the concept of inclusiveness could be materialised in contributing the actual information and data in reporting the country SDGs progression. Youth engagement in Indonesia is also evident through the consultation at various levels, particularly on various issues such as gender equality, child protection, and youth empowerment. These consultations such as the Woman and Child Musrenbang (Women Development Planning Meeting at District level), Village Discussion and Working Group on Violence against Women and Children, Village Children's Forum (FAD), and Consultation in Village Development Planning, which were led by various NGOs, Youth-led Organisations, and UN Agencies. Evidently, these programmes were in line with SDG 5, 10, 16, and 17.

Youth organisations and youth volunteers also contribute towards SDGs progression in Indonesia. For example, the youth volunteers adhered to SDG 13 by helping the government with the disaster-affected community and SDG 4 by sending 600 Young Educators under "Indonesia Teaches Programme" (Ministry of National Development Planning, 2019). Numerous youth organisations and youth groups for disabilities also disseminating SDGs to their fellow friends in various provinces in the country. In addition, to intensify the university roles as institutions that could promote SDGs and fulfil the concept of Education for Sustainable Development (ESD), the SDGs Campus Ambassadors was appointed to advocate the SDGs to the community within the campus and off the campus (Ministry of National Development Planning, 2021). By having this initiative, youth in Indonesia have performed their roles as agents of change and communicated the SDGs to the target groups.

As a target group, various issues related to youth has gained the government's attention. SDG 1 has always been one of the main concerns for Indonesia. With regard to that, SDG 4 in Indonesia has been strongly emphasised and was linked alongside SDG 1, 8, 10, and 17 to resolve poverty and unemployment. Therefore, the working capacity of youth irrespective of gender and geographical settings have been strengthened with formal education, training and development, mentoring, and financial assistance. As a result of the establishment of educational initiatives such as the "Indonesia Smart Programme", the school completion rate has risen, and the education participation rate of young people is maintained at a positive trend (Ministry of National Development Planning, 2019). The vocational and entrepreneurial training programmes for the school and non-school population have also been strengthened. A social-based entrepreneurship training for youth, for example, is to produce young entrepreneurs and to offer alternative employment. The government has allocated a specific budget for vocational training, work-based learning, and apprenticeship programmes that can facilitate the transitioning of youth from school to work. Also, the Vocational Training and Skills Centre and Community Learning Centre were established to offer numerous skill-based training to the young people (Ministry of National Development Planning, 2017, 2019). With the public-private collaboration and Corporate Social Responsibility (CSR) between the government institutions and businesses, the vocational training and programmes in Indonesia have increased the employment rate of the younger generation, including youth with disabilities. This was evident in the Link and Match 
programme and SINERGI (Strengthening Coordination for Inclusive Workforce Development in Indonesia) initiative.

However, due to the pandemic, it was reported in VNR 2021 that the unemployment rate in the country increased in 2020 compared to the previous year. The issue of equal access to employment according to gender and job opportunities to youth with disabilities is also highlighted. Additionally, a Focus Group Discussion (FGD) with youth representatives revealed that youth organisations encountered difficulties initiating SDG-related programmes throughout the pandemic, access to education was a challenge, and youth are experiencing mental health problems (Ministry of National Development Planning, 2021). As a result, the government has provided an internet package as part of the "School from Home" assistance programme to ensure the education continuation process, and "Sehat Jiwa" as an intervention programme on mental health issues.

In addition, the government has undertaken specific measures to address health concerns (SDG 3). Programmes to deal with chronic diseases, awareness on sex education for young people, good health practices and youth health and nutrition improvement programmes have been the country health provider's focus with UN agencies such as United Nations International Children's Emergency Fund (UNICEF) (Ministry of National Development Planning, 2017, 2021). As for the issues regarding gender equality (SDG 5), particularly on teenage and child marriage issues, the government has undertaken proactive actions to create public awareness through communicative and educational programmes (Ministry of National Development Planning, 2019). Environmental concern has also becoming youth attention in the country. The VNR 2021 has reported few youth-led initiatives, such as Plastic Reborn 2.0, to advocate sustainable plastic waste management. Teenagers were also engaged with technology in the advancement of SDG 13, in which the maritime and terrestrial weather forecast have been monitored with a smartphone application known as "Cuaca BMKG" (Ministry of National Development Planning, 2019). In general, Indonesia has reported their SDGs progress successfully by sharing their best practises. This will incentivize countries in the region to adapt and learn from these strategies.

\section{Laos}

Based on the Laos VNR (2018), the country SDGs implementation aligns with the 2025 Development Strategy and 2030 Vision. A cross-cutting approach has been pursued by concentrating on gender equity, youth, and empowerment. The youth and volunteers in Laos are engaged by consultations with various development partners, volunteer groups, and young people in Vientiane, Savannakhet, and Sekong. It aims to discover their SDGs knowledge, approach to leverage voluntary capacity, and commitments to specific SDGs (Laos Voluntary National Review, 2018). Various voluntary projects have also been initiated to achieve SDG 3, 4, 5, 10, and 16. For example, the Savannakhet Youth Resource Centre aims to empower vulnerable youth, low-income families, and human trafficking victims (Laos Voluntary National Review, 2018).

In addition, adolescent girls in Laos require special attention as the country experienced the highest rate of early marriages, early pregnancies, and maternal mortalities. On these matters, the government has successfully invested in health, nutrition, and education to minimise the issues. HIV and AIDS prevention is also one of the priorities of the government despite the difficulties in approaching high-risk populations (Laos Voluntary National Review, 2018). Thus, the strategic integrations of SDG 3, 4, 5, 16, and 17 are required to resolve this 
Vol. 10, No. 3, 2021, E-ISSN: 2226-6348 @ 2021 HRMARS

issue. The nexus between SDG 4 and 5 to promote gender equality through education is just as important. The Gender Parity Indices (GPIs) for secondary education and literacy in Laos showed that females remain less educated as compared to the males. The government has also introduced a non-formal education programme to equip students with proper skills as a preparation for them to become the future workforce (SDG 8) (Laos Voluntary National Review, 2018) since many students refuse to pursue secondary education. Considering that the young population of Laos have the capabilities for medium and high-skilled jobs, the government is active at establishing both regional and international collaborations through labour market cooperation and Foreign Direct Investment (FDI), particularly within the ASEAN Economic Community (AEC) framework (SDG 17).

\section{Malaysia}

Malaysia has submitted its VNR for the years 2017 and 2021. The SDGs in Malaysia is under the purview of the National SDGs Council, which is authorised by the Prime Minister of Malaysia. With the adoption of a "Whole of Nation and Whole of Society Approach", youth engagement is considered as one of the components in the National Steering Committee (NSC) at the SDGs Cluster Working Committees (CWC) (Economic Planning Unit, 2017). An example of youth engagement in the SDGs of Malaysia is the participatory bottom-up strategy that was established in 2017 by the Ministry of Youth and Sport in the "National Transformation 2050" (TN50) via town hall dialogue, online survey, and "Future Circles" group. More than 30000 sustainability-related insights from more than 680000 youth participation had been recorded.

Youth contributions and engagement in SDGs in Malaysia are highlighted in the second VNR compared to the previous one. For example, the Malaysian Youth Council (MBM) has represented the youth's voice in the CSO-SDG Alliance, a network of non-governmental organisations dedicated to advancing the SDGs and influencing SDG-related initiatives. Youth establishments also play significant roles in protecting the Malaysian environment. For example, Malaysian Youth Delegation and Klima Action Malaysia were established by passionate young individuals to represent the local youth climate movement and to raise Malaysians' awareness of climate policies (Economic Planning Unit, 2021).

Apart from that, youth assembly is an alternative avenue to gather responses from various youth NGOs and representatives. The assembly outputs for the Asia Pacific Urban Forum (APUF) 2019, Malaysia Urban Forum in 2019 and 2020, and Malaysia SDGs Summit in 2019 acted as a youth statement to "declare the action" towards Malaysia's SDGs. Also, volunteering programmes have attracted more than two million youth engagement through platforms that are advanced in SDGs-related activities, for instance, the Malaysian Youth Volunteering Programme (MyCorp), the Student Volunteers Foundation (YSS), 1Malaysia For Youth (1M4U), and the Malaysian Scout Federation. Additionally, the opinions of youth are being noticed in leadership initiatives such as the Perdana Fellow Programme and the Malaysian Youth Parliament.

As a country's development strategy incorporating SDG components, the Eleventh Malaysia Plan (2016-2020) sets out key strategies to enhance human capital development in becoming an advanced nation. However, the youth unemployment rate remains a major concern of the government. To maintain the competitive labour of the country, the $11^{\text {th }}$ Malaysia Plan Mid Term Review has outlined a few strategies to groom young skilled workers, which firstly involve the transformation of the Technical, Vocational Education and Training 
Vol. 10, No. 3, 2021, E-ISSN: 2226-6348 @ 2021 HRMARS

(TVET) programmes for the youth under the National Dual Training System (NDTS) and Future Workers Training scheme (SDG 8 and 10). Secondly, the establishment of young entrepreneur training programmes under Entrepreneur Development Organizations (EDOs) and StateOwned Enterprises (SOEs). The area of focus will be modern agriculture, oil and gas, automotive, aerospace, and defence industries (Ministry of Economic Affairs, 2018). In addressing the unemployment issues among the youth, the government has introduced Professional Training and Education for Growing Entrepreneurs (PROTÉGÉ) in offering skills for the young graduate and Malaysian@Work Initiative in providing better job opportunities (Economic Planning Unit, 2021).

Malaysia also focuses on poverty eradication (SDG 1 ) with the principle of equal treatment to all races. The welfare of the youth from the B40 categories continues to be at the government attention. For example, the government has provided 1432 affordable houses for youth and young married couples under the "Rumah Transit 1Malaysia" programme. The welfare of children and youth from B40 households will be further enhanced with the Bumiputera Economic Community (BEC). Simultaneously, micro-credit financing facilities will also be given to the Chinese and Indian communities. These initiatives will improve equitable growth and resolve socio-economic disparities (SDG 10 and 16). The quality of education (SDG 4) offered to the young generation is also the top priority of the government. With regard to that, STEM will be strengthened by incorporating theoretical and practical components. The quality of graduates and academic programmes at the universities will be assured by inculcating the six primary graduate attributes. Other improvements include Massive Open Online Courses (MOOC) and Integrated Graduate Employability Structured Programme (i-GESP). In addition to that, the youth will be educated and empowered (SDG 10) to retain women and children's rights and protection against violence. An integrated approach which involves several agencies such as Royal Malaysia Police (PDRM), Ministry of Education (MOE), Ministry of Health (MOH), NGOs, and the Department of Social Welfare (SDG 16) (Ministry of Economic Affairs, 2018) will also be conducted to educate the younger population and make them aware on various social illnesses, health, and juvenile crimes.

Malaysia's commitment to the SDGs is reflected in its policy and institutional frameworks, as reported in both VNR. However, SDGs progress at the state and local level are also considered necessary. The current state of affairs illustrates that only a few state governments in Malaysia have aligned their development plans with the SDGs. In addition, the discussion and empirical evidence on its practice is still limited. At the local level, the Shah Alam City Council (MBSA) and Subang Jaya City Council (MBSJ) are two of the leading local governments that have successfully completed the first Voluntary Local Review (VLR). This will motivate the remaining local governments to begin the SDGs localisation initiative.

\section{Myanmar}

Myanmar is the second country in the region that has not presented its VNR. However, the Myanmar Sustainable Development Plan 2018-2030 (MSDP) is considered the "Priorities of Priorities" as it highlights that the achievement of one SDG will contribute to the progression of other SDGs for the country. The first pillar of the MSDP is to "Promote Peace, National Reconciliation, Security, and Good Governance". In this pillar, the government prioritises peace in conflicted areas to ensure successful implementation of MSDP initiatives to achieve growth, reduce poverty, and create strong public institutions (SDG 16). For the movement to 
Vol. 10, No. 3, 2021, E-ISSN: 2226-6348 @ 2021 HRMARS

succeed, it requires the active participation of disadvantaged groups such as the youth. The prioritisation of youth by the government is more evident in "People and Earth", which is the third pillar of the MSDP. Besides that, the government has also concentrated on "Human Resources and Social Development for a $21^{\text {st }}$ Century Economy" in Goal 4 of the third pillar. Improvement on the education which is under the National Education Strategic Plan (20162021) in tandem with the SDG 4 was carried out to achieve this goal. Improving literacy and numeracy rates, ensuring equal access to high-quality lifelong learning, enhancing careerrelevant education streams, concentrating on TVET courses, and providing quality tertiary education opportunities are some of the approaches embraced by the government. Myanmar is also embedding $21^{\text {st }}$ Century skillsets into the national curriculum. Moreover, various initiatives have been provided for children and youth, such as school feeding programmes, school drop-out prevention programmes, anti-drug awareness programmes, back to school programmes, and vocational training programmes (Ministry of Planning and Finance, 2018). Overall, the reformed education of Myanmar aims to achieve SDG 2, 3, 4, 5, and 8.

The third pillar aims to provide an inclusive social safety net, eliminate poverty, and create greater economic mobility for the younger generation. Cash allowances, employment opportunities, and minimum wages are among the action plans to fulfil SDG 1, 3, 8, and 10. Furthermore, environmental conservation and sustainability will consider the viewpoint of youth in various decision-making processes in pursuing SDG 14 and 15 as youth is the present and future generation as defined in sustainable development. Investment in conservation and water-related services by the government have also been done to ensure proper water quality, sanitation, and hygiene are met for the city and young populations. Hence, the younger generation has been identified as the key players in urban governance, development, and planning to fulfil the SDG 11 (Ministry of Planning and Finance, 2018). Myanmar's commitment to implementing the global agenda is reflected in the MSDP, which is inextricably linked to the SDGs. This makes it worthwhile to study the effectiveness and accomplishments of existing policies, even more so when various aspects of sustainable development also focus on youth.

\section{The Philippines}

The Philippines SDGs have been driven by its long-term vision, which is "AmBisyon Natin 2040", and the Philippine Development Plan (PDP) 2017-2022, with its "Pagbabago" (Change) pillar. The SDG 1 has been tackled with a comprehensive stakeholder engagement by creating the National Anti-Poverty Commission (NAPC) that is presided by the President. It comprised members of the government and primary sectors, including youth, students, and children, which administer the Social Reform Agenda on poverty alleviation (SDG 1 and SDG 16) (The Philippines Voluntary National Review, 2019).

The Philippine Constitution promised the rights of its citizens to gain access to proper education (SDG 4). The Philippines are also excellent in providing education to all disadvantaged groups such as disabled individuals, indigenous peoples, out-of-school youth, and youth abroad. Quality education has been provided through the administration of various legislative measures such as the Governance of Basic Education Act of 2001, the Enhanced Basic Education Act of 2013, and the Open Distance Learning Act. Specific government aid and incentives such as the "DepEd school feeding plan" (SDG 2) and the "conditional cash transfer" were also implemented to encourage school attendance. Besides that, technology has also been incorporated into education by the integration among the government, private 
sectors, civil society, and academic institutions to provide training and job opportunities to underprivileged youth (SDG 17). A few examples were the Alternative Learning Programme, "Helping Ourselves", and the "K to 12 Plus project". In addition to that, the "Teach for the Philippines" programme has been playing an important role in sending young graduates to public schools to resolve the issue of shortage of teachers. The implementations of SDG 4, 5 , 8 , and 10 were also carried out by the nation to address multiple challenges.

The issue of inequalities in SDG 5 and 10 has been addressed through legislative measures, and by increasing the economic activities, human capital development in all industries, and balanced regional growth. The government has also passed the First Time Job Seekers Assistance Act to assist young job hunters and achieve a promising labour force participation rate (SDG 8). As a result, this has significantly reduced the unemployment rate and the number of non-educated youth (The Philippines Voluntary National Review, 2019). The youth engagement in the Philippines has been enhanced with the Youth Empowerment Summit for the SDGs, the Manila Declaration for the SDGs, and the SDGs Youth National Convergence. Youth leaders from various fields are committed to SDGs by determining the priorities of SDGs that are to be included in the SDGs action plans (The Philippines Voluntary National Review, 2016). The SDGs website of the country also offers a forum for greater youth participation. Overall, youth engagement in the Philippines SDGs is also well-reported and could be a guideline for other countries.

\section{Singapore}

From the Singapore VNR, several SDGs are targeting the youth in the country. For instance, the SDG 4 aims to equip the youth, adults, and people with disabilities (SDG 10) with technical and vocational skills, literacy and numeracy, better employment and wages, and entrepreneurship. Besides, the operationalisation of a global strategy for youth employment and the enforcement of the International Labour Organisation's Global Jobs Pact (SDG 8) have been carried out by the government.

Youth at schools are also responsible for SDG progression as the target group and programme implementors through partnership (SDG 17). Under SDG 11 and 12, the young people in ten schools had spread awareness on reducing food waste and converting the waste into compost to be used in the community garden through the "Love Your Food @ Schools" initiative. The initiative has been expanded through collaboration with other schools and community on waste minimisation and recycling activities. This initiative complements that of the integrated food waste management plan of Singapore to become a Zero Waste Nation. Also, the National Environment Agency (NEA) has affiliated with schools to create recycling corners and the Preschool 3R Awareness Kit to educate pre-school students on environmental conservation and recycling activities. For SDG 13, youth awareness on climate change has been incorporated into school curricula, field trips, and climate change planning and management. As for SDG 14, the Singapore Maritime and Port Authority (MPA) has also organised outreach and voluntary programs to raise awareness, as well as promote the marine protection and nature conservation to youth and students. To achieve SDG 16 and 17, the government collaborated with various parties to host a youth video competition, which was known as "The Sustainable Development Goals - What YOUth Can Do". Improvement of the Children's and Young Persons Act (CYPA) and Harassment Protection Act has also been carried out. Additionally, IKEA, which is a business entity, has also cultivated CSR initiatives 
INTERNATIONAL JOURNAL OF ACADEMIC RESEARCH IN PROGRESSIVE EDUCATION AND DEVELOPMENT

Vol. 10, No. 3, 2021, E-ISSN: 2226-6348 @ 2021 HRMARS

through youth-SDGs programmes and collaborated to promote sustainable and conscious businesses (Ministry of Foreign Affairs, 2018).

\section{Thailand}

Youth in Thailand has become part of the Open-Ended Working Group with civil Society (OEWG for SDGs) in contributing input for the VNR 2021. The Youth Council of Thailand, Youth in Charge and the Voice of Youth (VOY) project has been engaged in the VNR process. Furthermore, the National Economic and Social Development Council (NESDC) for SDG has youth representatives as the sub-committee, reflecting the importance of youth in the country's SDGs institutional mechanism (Ministry of Foreign Affairs of Thailand, 2021).

As stated in the first and second VNRs, youth roles are essential in Thailand, particularly in ensuring public understanding of the concept of Sufficiency Economic Philosophy (SEP) as the SDG-based development approach for the country. Therefore, the Thailand government has initiated youth consultation to educate the younger population on the concept of SEPSDG and organised activities to raise youth awareness on SDGs such as the "SEP for SDGs" speech and essay writing contests and Youth Forum on Sustainable Development. Thailand has also been holding a "Conference on South-South Exchange on Youth Volunteering for SDGs" and a youth symposium related to SDGs. All these efforts endorse the importance of youth in SDGs Thailand (Ministry of Foreign Affairs of Thailand, 2021; Thailand Voluntary National Review, 2017)

In both VNR 2017 and 2021, the Thailand government has focused on issues related to youth, particularly in education, health, employment, and welfare protection. Government action in addressing these issues is to improve the area of concern in SDG 3, 4 and 10 and address poverty (SDG 1 ) in a bigger picture to achieve the objectives outlined in the $12^{\text {th }}$ National Economic and Social Development Plan. For example, the Cottage Industries Centre for the women of the local ethnic minority in the province of Chiang Rai was set up by Mae Fah Luang Foundation to improve their quality of life through craftsmanship. The Women and Family Development Learning Centres have also provided vocational training for vulnerable local women and youth in juvenile centres (Thailand Voluntary National Review, 2017). In VNR 2021 , youth roles are more evident in improving the SDG 1,2,3,4. Through voluntary works, the youth movement was reported at the frontline in protecting the welfare of the vulnerable community, especially during the COVID-19 pandemic. For example, the "Khon Kaen COVID Fight Project" and "Youth Networks for Food Security" have involved youth organisations and volunteers in ensuring the homeless and vulnerable community received appropriate protection during the crisis (Ministry of Foreign Affairs of Thailand, 2021). The youth volunteers movement in Thailand also intervenes in mental health issues as it was reported that youth in the country suffered from depression due to COVID-19. At the same time, the Youth Council of Thailand is playing a role in raising youth awareness and combating teenage pregnancies.

In environmental protection, Thailand aims to improve the air quality of the cities and waste management by 2030 in order to achieve SDG 11 and 13. The National Disaster Prevention and Mitigation Plan 2015, Climate Change Management Master Plan (2015-2050), and the Community Disaster Risk Management (CBDRM) have been integrated at localities for implementation. For example, the children and youth of every household and community were encouraged to practice proper garbage sorting by the municipality of Khon Kaen. Simultaneously, Baan Limthong Community in Buriram Province has planned and facilitated 
Vol. 10, No. 3, 2021, E-ISSN: 2226-6348 @ 2021 HRMARS

youth activities with technology to resolve the issue of water shortage. In VNR 2021, the government has continued to intensify the community participation and development of water quality for the younger population to ensure they have access to clean water. As to promote renewable energy, the "Power for Sustainable Future Foundation" has organised workshops to educate youth and other groups of the community on energy sustainability (Ministry of Foreign Affairs of Thailand, 2021). Furthermore, the "Happy Village based on 9 Virtues" programme has empowered and inspired Buriram's youth to enjoy sustainable peace.

SDG 5 and 8 were also the focal points of Thailand in VNR 2017, particularly regarding young women and youth. Lastly, the Kamlangjai (Inspire) project under SDG 16 and 17 aims to assist the young offenders with their judicial process and help them reintegrate into the community. For example, the cooperation with the UNICEF will ensure children and youth have equal and inclusive access to justice and are given proper legal protection (Thailand Voluntary National Review, 2017).

\section{Vietnam}

The policies for SDGs in Vietnam include the Strategic Orientation for Sustainable Development in Vietnam (Vietnam Agenda 21), Strategy for Sustainable Development (20112020), and SDG National Action Plan (NAP). In VNR 2018, the young people were one of the government partner for SDGs, and it became evident when the SDGs were mapped with the Vietnam Youth Development Strategy (2011-2020) (Vietnam Voluntary National Review, 2018). Moreover, Vietnam has been making significant progress in both SDG 16 and 17 with the establishment of the UN SDG Technical Working Group, engagement with local and international partners, media coverage, and compliance with various international conventions on environmental protection and sustainable development. Extensive attention with multi-stakeholders was evident in the preparation of VNR, which included the UN agencies, legislators, ministries and its agencies, business sectors, researcher, scientists, and NGOs such as Youth Union.

As stated in its VNR, several laws and policies regarding health have been reviewed and released for SDG 3, which include laws on HIV/AIDS and other health laws to control teenage pregnancy and to ensure women and young people have equal access to health facilities (Vietnam Voluntary National Review, 2018). This indicates that the importance of health protection to the youth has become one of the government's concerns.

Apart from that, education (SDG 4) is also one of the national priorities as the government has allocated $20 \%$ of funding for the development of education to offer quality education and lifelong learning. Various laws and policies that are related to vocational education and training have been reviewed based on the Education Development Strategy (2011-2020). The laws and policies were incorporated in the TVET Development Strategy (2011-2020), Vietnam Youth Development Strategy (2011-2020), Education Universalisation and Illiteracy Eradication, Action Plan on Gender Equality in Education (2016-2020), National Law on Persons with Disabilities (2012), and Inclusive Education Guidelines for Persons with Disabilities. Technical education was integrated with the local economic sector to carry out the plan, providing an income source for the youth participant. For instance, a training session on the community-based water resource management model for shrimp farming was held for the youth of Thuy Lac and Thu Pho villages. The project was conducted by the Environmental and Community Research Centre in Nam Phu Commune, Tien Hai District, and Province of 
INTERNATIONAL JOURNAL OF ACADEMIC RESEARCH IN PROGRESSIVE EDUCATION AND DEVELOPMENT

Vol. 10, No. 3, 2021, E-ISSN: 2226-6348 @ 2021 HRMARS

Thai Binh (Vietnam Voluntary National Review, 2018). Overall, the strategies specific for SDG 4 can also contribute to SDG 5, 6, 8, 9, and 10 progressions.

\section{Discussion and Recommendation}

The discussion in the previous section enabled the authors to map the SDG-youth-related initiatives that were implemented in ASEAN countries. Table 1 indicates that all the ASEAN countries have embedded the youth-related initiatives in more than one SDG to signify youth's importance towards the Agenda 2030 accomplishments. Based on Table 1, ASEAN countries have focused more on SDG $3,4,5,8,10,16$, and 17 through multiple capacities, institutional building, and policy arrangement. This indicates that the SDGs focus on youth in this region is consistent with the four domains in the ASEAN YDI, namely health, education, employment, and partnership. Each country has adopted different mechanisms in approaching the SDGs, dependent on its political system and policy framework. However, this will not impede the adaptation strategies as the universal SDGs can be achieved by incorporating the best practices from other countries.

SDG 4 on quality education has been the primary focus of the ASEAN countries and has been integrated with the other SDGs to provide additional benefits for socio-economic development and contribute to the other SDGs' progress. Hence, TVET and STEM were recognised and incorporated by almost all countries into their education system to produce skilled social capital. This is because it could contribute to SDG 8 progression on employment and addressing SDG 1 issue on poverty. However, more reports on Education for Sustainable Development (ESD) that mobilise youth at various levels of education are highly needed. This is because, through the educational system, the SDGs progression could be achieved through formal and informal activities at the school and university levels, as reported by de Cámara et al. (2021), Mawonde and Togo (2021) and Tunji-Olayeni et al. (2021).

The evidence on youth engagement in this region, particularly in environmentalrelated goals such as SDG 6, 7, 12, 13, 14, and 15, was also limited. So far, however, there has been little discussion about the environmental SDGs in the VNR involving the youth, except on climate change initiatives, water quality, sustainable energy, and waste management. The lack of reports in the VNR on youth engagement in environmental activities indicates that more information needs to be obtained from environmental activists and NGOs. Youth exposure to ecological protection is needed as they will inherit the planet and its natural resources. Their engagement in the environmental-related goals should be reported in VNR and will be evidence under the SDG's environmental dimension.

The subject of inclusiveness and partnership in SDG 16 and 17 have been viewed as the regional mechanism to utilise youth strength through CSR, public-private partnerships, and voluntary works. All countries in this region have created youth inclusiveness and partnership in SDGs implementation and evaluation through VNR. However, their degree of inclusiveness and partnership vary, depending on the country's SDGs practices. Since one SDG achievement will contribute to other SDGs' progression, a similar engagement apparatus could be replicated by the countries in this region as the foundation for localising the SDGs.

Figure 1 illustrates the forms of youth engagement in SDGs activities in the region. The first group of youth are the "provider" for SDGs activities and are engaged through voluntary works, youth organisations, and government partners. They are involved in SDGs reporting, data collection, public consultation, and roles as initiators in community projects. The second group is the SDGs "receiver". The youth in this group take on the role of participants and 


\section{INTERNATIONAL JOURNAL OF ACADEMIC RESEARCH IN PROGRESSIVE EDUCATION AND}

DEVELOPMENT

Vol. 10, No. 3, 2021, E-ISSN: 2226-6348 @ 2021 HRMARS

recipients in education, health services, training and development, and are involved in multilevel meetings due to their limited capacities. They are the target group for most of SDGs related programmes. The third group of youth act simultaneously as the SDGs "provider and receiver" and engage with the government as the SDGs policymakers and city planners. They also participate in high-level discussions, communicate through the virtual platform, and are involved in CSR activities. Overall, youth engagement in SDGs in this region is easily achieved through voluntary works and youth-led activities.

The strengths and volume of this group of youth vary depending on the desire of the government in accepting the youth as their partners. The meaningful engagements in formal policy decision-making, which are mainly related to SDGs, is critical as only a few countries have a specific institutional arrangement that positions youth representative. Besides that, youth with disabilities should be given equal opportunities to ensure the proper development of all individuals by the global agenda.

A profound analysis is required in measuring and comparing the progress of SDGs in this region. Extensive development plans, UN reports, and official data are needed as the VNR of the countries provide minimal information on the current progress of SDGs development particularly related to youth engagement and their procedures. Additionally, the national reporting should be conducted frequently and the input from various stakeholders should be gathered systematically to give a clear and concise idea on the recent SDGs achievement, thus, allowing the exchange of practices among different countries.

With the guides of UN agencies, ASEAN cities are also encouraged to commence their VLR to report the SDGs progress of their cities at a local level. This practice will provide comprehensive data towards SDGs progression at the lower level implementation and support the global and national SDGs reporting. Simultaneously, establishing SDGs at the local level will enable the government to communicate and interact with the younger generation within SDGs easily. Furthermore, the Sustainable Development Report 2020 highlighted the effect of COVID-19 on youth and its impact on the progressions of SDGs (Sachs et al., 2020). Hence, further research on exploring the engagement between the youth and SDGs during and post-pandemic is highly crucial. 
INTERNATIONAL JOURNAL OF ACADEMIC RESEARCH IN PROGRESSIVE EDUCATION AND DEVELOPMENT

Vol. 10, No. 3, 2021, E-ISSN: 2226-6348 @ 2021 HRMARS

Table 1. Mapping on SDGs-Youth Related Initiatives as Reported in the ASEAN Countries VNR and Development Plans.

\begin{tabular}{|c|c|c|c|c|c|c|c|c|c|c|c|c|c|c|c|}
\hline 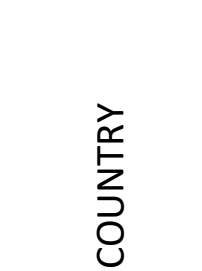 & $\begin{array}{l}\bar{\Phi} \\
\frac{\bar{\nu}}{\grave{D}} \\
\end{array}$ & $\begin{array}{l}\frac{\pi}{\overline{0}} \\
\frac{0}{0} \\
\frac{0}{E} \\
\tilde{U}\end{array}$ & & 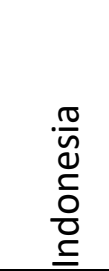 & & 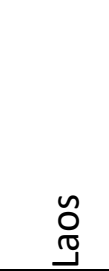 & & $\frac{\frac{\pi}{\sqrt{2}}}{\frac{\pi}{\pi}}$ & 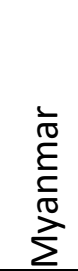 & & 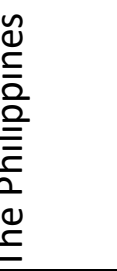 & 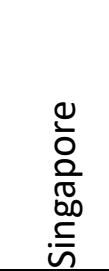 & & 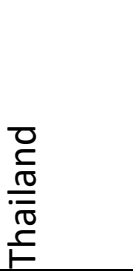 & $\begin{array}{l}\varepsilon \\
\stackrel{E}{0} \\
\stackrel{+}{ \pm} \\
\stackrel{0}{J}\end{array}$ \\
\hline SDG/YEAR & $a$ & 2019 & 2017 & 2019 & 2021 & 2018 & 2017 & 2021 & $\mathrm{~b}$ & 2016 & 2019 & 2018 & 2017 & 2021 & 2018 \\
\hline SDG 1 & & & $\mathrm{~V}$ & & $\mathrm{~V}$ & & $\mathrm{~V}$ & & $\mathrm{v}$ & & $\mathrm{V}$ & & $\mathrm{V}$ & & \\
\hline SDG 2 & & & & & V & & & & v & & V & & & V & \\
\hline SDG 3 & & v & v & & v & v & & & v & & & & v & v & v \\
\hline SDG 4 & V & v & & v & $\mathrm{v}$ & v & v & & v & & V & v & v & v & v \\
\hline SDG 5 & & v & v & & v & v & & V & v & & V & & v & v & v \\
\hline SDG 6 & & v & & & & & & & & & & & & & v \\
\hline SDG 7 & & & & & & & & & & & & & & v & \\
\hline SDG 8 & V & v & & v & v & v & v & V & v & & V & v & v & v & v \\
\hline SDG 9 & & & & & v & & & & & & & & & & v \\
\hline SDG 10 & & & & v & v & v & v & & v & & V & v & v & v & v \\
\hline SDG 11 & & v & & & $\mathrm{V}$ & & & & v & & & v & v & v & \\
\hline SDG 12 & & v & & & v & & & & & & & v & & & \\
\hline SDG 13 & & & v & v & & & & V & & & & v & v & & \\
\hline SDG 14 & & & & & & & & & v & & & v & & & \\
\hline SDG 15 & & & & & v & & & & v & & & & & & \\
\hline SDG 16 & V & v & & v & v & v & v & V & $\mathrm{v}$ & v & & v & v & v & v \\
\hline SDG 17 & V & v & & v & v & v & v & V & & & v & v & v & v & v \\
\hline
\end{tabular}

a Brunei SDGs mapping was based on the 10th and 11th NDP, The Brunei Vision 2035 Documents, and UNESCO Country Strategy 2018-2023.

b Myanmar SDGs mapping was based on the MSDP (2018-2030). 


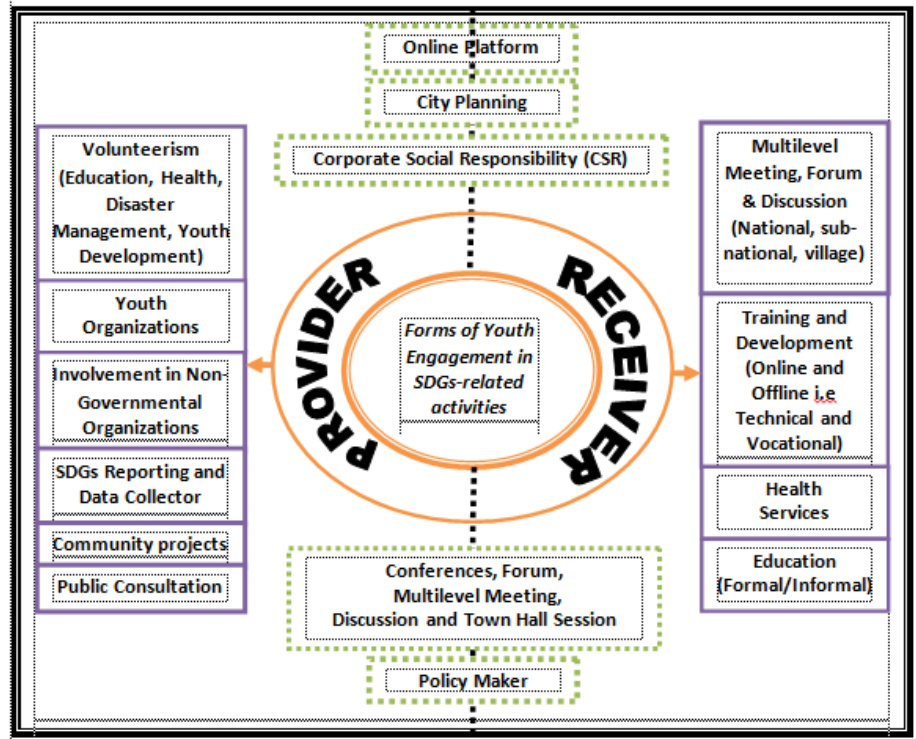

Figure 1. Youth Engagement Diagram (Adapted from the Countries SDGs VNR and NDP)

\section{Conclusion}

As a conclusion, ASEAN countries have made significant progress in the efforts to develop the SDGs. The implementation of policy arrangements such as the specific national development plans and SDGs framework of a particular country required continuous political will and support from various stakeholders. As the younger generation of a country, youth should benefit from the SDGs initiatives and strive to contribute to their country's development. The stakeholder's engagement and youth empowerment will promote significant cooperation amongst the stakeholders to create a sustainable policy at various recursive levels. COVID-19 is a global pandemic, and SDGs progression should be maintained at these challenging times. Hence, the ASEAN youth community can play a global role in fostering sustainability across multiple platforms such as social media, increasing opportunities for greater recognition and creating stronger youth solidarity.

\section{References}

De Cámara, E. S., Fernández, I., \& Castillo-eguskitza, N. (2021). a holistic approach to integrate and evaluate sustainable development in higher education. the case study of the university of the basque country. sustainability, 13(392), 1-19.

https://doi.org/10.3390/su13010392

Department of Economic Planning and Development. (2012). brunei darussalam: tenth national development plan (2012-2017).

https://policy.asiapacificenergy.org/sites/default/files/rkn english as of

11.12.12_red.pdf

Department of Economic Planning and Statistics. (2020). eleventh ndp (2018-2023) brunei

Darussalam: increased non-oil and gas sector output as catalyst for economic growth. http://www.deps.gov.bn/sitepages/eleventh national development plan.aspx

Economic Planning Unit. (2017). Malaysia sustainable development goals voluntary national review 2017: high level political forum.

Https://sustainabledevelopment.un.org/content/documents/15881malaysia.pdf

Economic Planning Unit. (2021). malaysia voluntary national review (vnr) 2021. 
https://sustainabledevelopment.un.org/content/documents/285982021_vnr_report_ malaysia.pdf

Laos Voluntary National Review. (2018). lao people's democratic republic: voluntary national review on the implementation of the 2030 agenda for sustainable development. https://sustainabledevelopment.un.org/content/documents/19385lao_final_vnr_19_ju ne_2018_web.pdf

Mawonde, A., \& Togo, M. (2021). challenges of involving students in campus sdgs-related practices in an odel context: the case of the university of south africa (unisa). international journal of sustainability in higher education.

https://doi.org/10.1108/ijshe-05-2020-0160

Ministry of Economic Affairs. (2018). mid-term review of the eleventh malaysia plan, 20162020: new priorities and emphases.

https://www.talentcorp.com.my/clients/talentcorp_2016_7a6571ae-d9d0-4175-b35d$99 \mathrm{ec} 514 \mathrm{f} 2 \mathrm{~d} 24 /$ contentms/img/publication/mid-term review of 11th malaysia plan.pdf

Ministry of Foreign Affairs. (2018). singapore's voluntary national review report to the 2018 un high-level political forum on sustainable development: towards a sustainable and resilient singapore.

https://sustainabledevelopment.un.org/content/documents/19439singapores_volunta ry_national_review_report_v2.pdf

Ministry of Foreign Affairs of Thailand. (2021). thailand's voluntary national review on the implementation of the 2030 agenda for sustainable development, 2021. https://sustainabledevelopment.un.org/content/documents/279482021_vnr_report_t hailand.pdf

Ministry of National Development Planning. (2017). voluntary national review (vnr): eradicating poverty and promoting prosperity in a changing world. https://sustainabledevelopment.un.org/content/documents/15705indonesia.pdf

Ministry of National Development Planning. (2019). voluntary national reviews (vnr): empowering people and ensuring inclusiveness and equality.

https://sustainabledevelopment.un.org/content/documents/23803indonesia_final_cet ak_vnr_2019_indonesia_rev2.pdf

Ministry of National Development Planning. (2021). indonesia's voluntary national review (vnr) 2021. https://sustainabledevelopment.un.org/content/documents/280892021_vnr_report_i ndonesia.pdf

Ministry of planning. (2019). cambodia's voluntary national review 2019, on the implementation of the 2030 agenda for sustainable development. https://sustainabledevelopment.un.org/content/documents/23603cambodia_vnr_publ ishinghlpf.pdf

Ministry of Planning And Finance. (2018). myanmar sustainable development plan 2018-2030 (issue august).

https://themimu.info/sites/themimu.info/files/documents/core_doc_myanmar_sustai nable_development_plan_2018_-_2030_aug2018.pdf

Sachs, J., Schmidt-traub, G., Kroll, C., Lafortune, G., Fuller, G., \& Woelm, F. (2020). the sustainable development goals and covid-19. sustainable development report 2020. https://s3.amazonaws.com/sustainabledevelopment.report/2020/2020_sustainable_d evelopment_report.pdf 
Thailand Voluntary National Review. (2017). thailand's voluntary national review on the implementation of the 2030 agenda for sustainable development. https://sustainabledevelopment.un.org/content/documents/16147thailand.pdf

The Asean Secretariat. (2017). first asean youth development index. https://asean.org/wpcontent/uploads/2017/10/asean-unfpa_report_web-final-05sep.pdf

The Philippines Voluntary National Review. (2016). voluntary national review at the 2016 high-level political forum on the sustainable development goals (sdgs): philippines. https://sustainabledevelopment.un.org/content/documents/10765ph voluntarynationalreview_final.pdf

The Philippines Voluntary National Review. (2019). the 2019 voluntary national review of the philippines: review of the status of the implementation of the sustainable development goals in the philippines focusing on empowering people and ensuring inclusiveness and equality.

https://sustainabledevelopment.un.org/content/documents/23366voluntary_national _review_2019_philippines.pdf

Tunji-olayeni, P. F., Adegboye, F., Oluwatobi, A., Adeyemi, G., Olagunju, O., Okoro, A., \& Osabuohien, E. (2021). accelerating progress on sustainable development goals: assessing secondary school students' knowledge of climate change actions. iop conf. series: earth and environmental science, 665, 1-12. https://doi.org/10.1088/1755$1315 / 665 / 1 / 012041$

Undesa. (2020a). the 17 goals. https://sdgs.un.org/goals

Undesa. (2020b). world youth report: youth, social entrepreneurship and the 2030 agenda. https://www.un.org/development/desa/youth/wpcontent/uploads/sites/21/2020/07/2020-world-youth-report-full-final.pdf

Unesco. (2018). brunei darussalam: unesco country strategy 2018-2021. https://unesdoc.unesco.org/in/documentviewer.xhtml?id=p::usmarcdef_0000263492 \&file=/in/rest/annotationsvc/downloadwatermarkedattachment/attach_import_49c5c 1a5-a4f7-4aff-86acb66ea704d192\%3f_\%3d263492eng.pdf\&locale=en\&multi=true\&ark=/ark:/48223/pf00 0026349

Vietnam Voluntary National Review. (2018). Vietnam's voluntary national review on the implementation of the sustainable development goals. In voluntary national review 2018.

https://sustainabledevelopment.un.org/content/documents/19967vnr_of_viet_nam.p df 